\title{
Enhancing the outcomes in R\&D collaborative projects: an empirical analysis of the Middle Ebro Valley in Spain
}

\section{Abstract}

The collaboration for developing research and development (R\&D) projects highlights the importance to access new external knowledge. Drawing from a mixed-methods approach in a sample of projects carried out by Spanish firms, our key findings show that every project's dimension of absorptive capacity is related to collaborative performance in different ways. Organisations with capability difficulties to transform external knowledge enhanced their R\&D projects' outcomes by collaborating more intensively. However it is the ability to exploit that external knowledge into innovation which could be the key to obtain outcomes and support to R\&D programs. The regional particularities have showed new ways to collaborate due to the innovation culture in the Middle Ebro Valley.

\section{Keywords}

Collaborative R\&D projects; project outcomes; absorptive capacity of knowledge; market orientation; regional innovation system; dynamic capabilities 


\section{Introduction}

Technological change and turbulences in the economic systems press organisations to acquire external knowledge to sustain their competitiveness. Moreover, some innovation paradigms and practices are based on the lack of internal capacities and their relationship with other organisations and individuals to look forward to future challenges (e.g., open innovation, joint technology initiatives, research joint ventures, communities of practices). Collaborative research and development (R\&D) partnerships are valuable because they enhance the firm's competitive advantage (Balachandra \& Friar, 1997; Gulati, Nohria, \& Zaheer, 2000; Zollo, Reuer, \& Singh, 2002; Zollo \& Winter, 2002). Firms do not only need in-house capabilities and knowledge to compete, but also require having access to flows of external knowledge. Among the reasons to develop projects with external partners are lower cost, risk diversification, complementarities exploitation, time reduction in developments and earlier access to emerging technologies.

Technological collaboration could be defined as any relationship between independent economic agents to carry out innovation activities (Hagedoorn \& Schakenraad, 1993; Hagedoorn, 2002). Nevertheless, implementing a R\&D project requires the explicit involvement of all partners in every objective and outcome (Veugelers \& Cassiman, 1999). The difficulties to manage alliances have been studied (e.g., Numprasertchai \& Igel, 2005) and several scholars remark the importance of managerial practices that increase the flexibility and communication workflows, or the ability to keep objectives on track (among others, Barnes, Pashby, \& Gibbons, 2006; Ciborra, 1991; Oster, 1992; Szulanski, 1996; Weck, 2006). The present study focuses on R\&D collaborative projects, the managerial practices needed to set up and execute them, and the outcomes obtained at the end.

Organisational skills that identify, negotiate, manage, control and eventually establish alliances configure a learning ability (Feller, Parhankangas, Smeds, \& Jaatinen, 2013), although each firm 
has a distinctiveness talent to assess the value of new external information and its own capabilities to transform and use it for commercial purposes. Thereby, the absorptive capacity of identifying, assimilating, transforming and exploiting knowledge $(A C)$ may contribute to improve innovation performance and it is considered by some scholars as a firm's dynamic capability (Escribano, Fosfuri, \& Tribó, 2009; Fosfuri \& Tribó, 2008; Teece, Pisano, \& Shuen, 1997).

Another important background for innovation studies is that, depending on the purpose of the analysis, innovation systems could not concur with the national borders. Studies focused on 'Regional Innovation Systems' are dedicated to analyze innovative activities within geographic regions at the supra-national or sub-national level (Carlsson, 2006). Proximity between partners could have a positive effect on the outcomes of the collaboration. Likewise, geographic proximity provides a closer relation between partners in $R \& D$ cooperative agreements (Bonaccorsi \& Piccaluga, 1994; Mora-valentin, Montoro-sanchez, \& Guerrasmartin, 2004), and several studies focus at regional level to determinate the nature of R\&D alliances,successes and failures (among others Becker \& Dietz, 2004; Lhuillery \& Pfister, 2009; Shimizutani \& Todo, 2008). The regional context could provide a new framework of analysis to explain the differences of drivers and consequences of AC. This may open new venues to establish regional programmes that support technology development and transfer between firms and research centers.

Following prior research about the topic, the majority of studies that analyse $A C$ rely on aggregated proxies such as R\&D expenditures/turnover to explain the firm`s differences of capacity and performance. Other studies develop and validate scales to measure the firm's absorptive capacity (among others Camisón \& Forés, 2010; Tessa Christina Flatten, Greve, \& Brettel, 2011; Jansen et al., 2005; Szulanski, 1996; Volberda, Foss, \& Lyles, 2010; Zahra \& George, 2002b) according to the relevance of each AC dimension which are not conclusive and requires deeper analyses (Arbussà \& Coenders, 2007; Arora \& Gambardella, 1994; Cassiman \& 
Veugelers, 2000) because there is not academic agreement so far about the optimum number of dimensions to access and use knowledge (Todorova \& Durisin, 2007). However the regional dimension and the analysis of $A C$ at project level inside the organisations are mostly absent from the literature.

Exploration and exploitation of knowledge have been studied in the areas of organisational learning and technological innovation (March, 1991). however very few use a unique database to examine the phenomena and show the positive impact on technological outcomes (McMillan, 2015).

The relationship of project managerial practices with firm capabilities and knowledge management are growing areas of importance (Bakker, Cambré, Korlaar, \& Raab, 2011; Biedenbach \& Müller, 2012; Mitchell, 2006) for managers and policy-makers, due to the increase of R\&D alliances and their public support at both national and regional levels. Therefore, it is necessary to explore new venues of research related to $A C$ in order to reconcile non-conclusive results from the $\mathrm{AC}$ literature, and to analyse the missing regional context that may influence the $\mathrm{AC}$ dimensions.

The contribution of this article to the analysis of R\&D collaborative projects is threefold. First, it explores the relation between the $A C$ and collaboration outcomes. The level of analysis includes project management practices and market orientation that improve project performance. Second, the different relationships between each dimension of the AC and performance show to scholars how to carry out deeper analysis about how firms may acquire, transform and exploit new knowledge. Third, the empirical analysis is based on a Spanish survey, whose results have been discussed with innovation managers in order to make recommendations for managers and regional policy-makers. Lundvall (2007) acknowledges the importance of firms as the units that play the most important role in the innovation system. This is the first stepto study a innovation system: what takes place inside the firms in 
terms of innovation and competence building?, and we do it throughout a quantitative study. According to Lundvall, the second step would be to analysis the interaction among firms and how they interact with the regional knowledge infraestructure (B. Lundvall, 2007, p. 102), that we cover throughout an explorative study.

The paper is structured in four sections. Next we summarize the literature with a background on open innovation and knowledge management in order to focus on R\&D collaboration and project management, by emphasizing the relevance of $A C$ as a dynamic capability; this second section also provides an overview of the innovation environment in the Middle Ebro Valley region. The third section describes the determinants of R\&D collaborative projects outcomes, the methodology of variable selection, construction and analysis, as well as we present the main results of the study. The fourth section discusses the link between the findings of the quantitative and the qualitative study by taking into account both the regional context and collaboration outcomes, and offers some concluding remarks, as well as managerial and policy implications.

\section{Theoretical background}

\subsection{Open innovation and knowledge management}

The paradigm of Open Innovation is useful for the theoretical background of our paper. Going back to the root, Chesbrough, West, \& Vanhaverbeke (2006) defined open innovation as 'the use of purposive inflows and outflows of knowledge to accelerate internal innovation and to expand the markets for external use of innovation, respectively'. By adopting an open innovation approach, firms can pursue innovation in different ways, either by enriching their own skills and knowledge with external sources of technology, by bringing knowledge to the market, or by combining the two above.

In comparison with an older literature of innovation, this paradigm provides a new perspective concerning external collaboration, thus making possible to highlight when a simple 
collaboration turns into an open innovation relationship because open innovation is always more than collaborative innovation. As stressed by West \& Gallagher (2006), open innovation implies to systematically explore a wide range of internal and external sources for innovation opportunities, consciously integrating that exploration with firm capabilities and resources, and broadly exploiting those opportunities through multiple channels. Conversely, the traditional approach to collaboration is characterized by a more occasional exploitation of external partnerships which makes absorptive capacity a more isolated and non-strategic phenomenon than when open innovation is really adopted.

From an analysis of prior research on how firms leverage external sources of innovation as well as from a review of 291 open innovation-related publications, West \& Bogers (2014) suggest a four-phase model in which a linear process -(1) obtaining, (2) integrating, and (3) commercializing external innovations- is combined with (4) interaction between the firm and its collaborators. The review of the literature finds that researchers have focused more of analyzing the obtaining phase of this process, whereas there is a relative dearth of research related to integrating and commercializing innovations. The interesting find for us is that integrating innovations have been mostly studied from an absorptive capacity perspective, even though with less attention given to the impact of competencies and culture (including "not invented here"). However the study of the influence of absorptive capacity on collaboration for innovation shows conflicting predictions and results: some suggest that absorptive capacity reduces the need for collaborations, while others argue that it increases the likelihood that firms will do so. Perhaps more frequently, scholars have argued that absorptive capacity makes remote collaboration more effective (de Jong \& Freel, 2010), and firms with a broader knowledge base are more likely to externally source technologically "distant" technologies (Laursen, Leone, \& Torrisi, 2010). Other shortcoming found in the open innovation literature (i.e., Chiaroni, Chiesa, \& Frattini, 2011) is that open innovation has been mainly analyzed in large, high-tech multinational enterprises but few studies exists in small and 
medium enterprises (SMEs). However, SMEs are also opening their innovative process, probably forced by the need of external resources in order to develop and commercialize new products which makes external networking and absorptive capacity some very important activities for these firms (Bigliardi \& Galati, 2013).

Recent studies also reveal that firms that have successfully capitalized on integrating external sources of knowledge into their innovation processes primarily are characterized by organizational flexibility and a willingness to restructure their existing business models to accommodate open innovation strategies (Saebi \& Foss, 2015). Open innovation requires the development of capabilities to manage the various knowledge processes such as knowledge exploitation, exploration and retention processes that take place between the firms and its environment. Notably, absorptive capacity is placed as a key mediating role between external knowledge and innovation. It supports the firms in first, identifying and acquiring external know-how, and, second, transforming and incorporating the newly obtained knowledge into the firm's existing knowledge base. To effectively harness the potential benefits of open innovation, firms need to employ various organizational and managerial practices for knowledge sharing, as well as having in-house research capacity and cross-functional collaboration between departments in the innovation processes in order to facilitate accessing and integrating knowledge residing outside the firm's boundaries (Salge, Bohné, Farchi, \& Piening, 2012).

Therefore, given the importance of knowledge management for open innovation, resourcebased theory (Grant, 1991) and knowledge-based theory (Grant, 1996) are also useful for rooting the theoretical background of the paper. The knowledge-based theory of the firm considers knowledge as the most strategically significant resource of a firm. Its proponents argue that because knowledge-based resources are usually difficult to imitate and socially complex, heterogeneous knowledge bases and capabilities among firms are the major determinants of sustained competitive advantage and superior corporate performance. Open 
innovation is indeed all about leveraging and exploiting knowledge generated inside and outside the firm to develop and exploit innovation. Implementing open innovation means to adopt knowledge management systems able to foster the diffusion, sharing and transfer of knowledge within the firm, and between the firm and external environment. For instance Yström, Aspenberg, \& Kumlin (2015) find that networking and cross-functional meetings within open innovation arenas where partner organizations meet to innovate together are beneficial to facilitate a creative climate. If the knowledge needed to accomplish either knowledge generation or selection is widely distributed among independent external actors, the association boundary is fundamentally different than when such knowledge is narrowly held within a firm. The more either solution generation or selection knowledge is broadly held, the greater the use of open innovation processes. In contrast, to the extent that either solution or selection knowledge is narrowly concentrated in the firm, the more internal boundaries dominate (Benner \& Tushman, 2015). The interrelationship between open innovation and knowledge management make a productive environment for R\&D projects to success.

\subsection{Scope of the R\&D collaborative projects in Middle Ebro Valley region}

According to the literature on regional innovation systems, the region as a territorial configuration is the most suitable spatial level to analyse and understand how firms acquire external knowledge for their innovation processes (Varis \& Littunen, 2012). Since regional innovation is positively related to knowledge spill-overs, several studies support that the regional attractiveness for firms is based on the region's knowledge-intensiveness, as well as in the high concentration of knowledge capital, and resources to market new ideas (Fritsch and Franke, 2004, cited by Beugelsdijk, 2009).

This study was carried out in the Spanish region that involves the Middle Ebro Valley (MEV) which includes Aragón, Navarra, and La Rioja municipalities. The Ebro River is a natural and historical transportation landmark of the territory that has linked people and economic 
activities for centuries. Municipalities in the area share socio-political and economic characteristics that fully support a comprehensive analysis at regional level. Common characteristics along the Ebro River region are its low population density, the intensive presence of some sectors based on the exploitation of natural resources (such as agricultural and agri-food industry), the implementation of large multinationals based in the area (for instance, automotive and consumer electronics industries), and the slightly higher standard of living than the Spanish average ${ }^{1}$. The region is located in the northeast of Spain. In 2010, its population was $2,311,299$ inhabitants, and the percentage of total workforce dedicated to R\&D activities (full-time equivalent) was $1.46 \%$ which is higher than the Spanish average (1.21\%). In high-technology activities, the percentage of R\&D personnel was $2.65 \%$; lower than average on Spain $(3.48 \%)^{2}$. Despite all the above, public administration, firms and universities invested $824,844,000$ euros in R\&D in the year 2010, a 57.59\% increase over the year 2005 , which indicates the relevance of the R\&D effort at regional level during the last years ${ }^{3}$.

Science and technology regional policies were supply-side oriented (technological centres) from mid-1980s to the mid-2000. Since mid-2000, emphasis changed towards demand-side oriented policies (vertical and relational clusters of companies), and since 2008 the support to innovations in Small and Medium Enterprises (SMEs) was more related to collaborative projects. Most of the companies in the region are small firms as they have less than fifty employees $(98 \%)^{4}$. Despite of the small size of the firms, there is a widely recognition of the quality of the research, outcomes and innovations developed at regional level. For instance, the national patents application (number of patents per million inhabitants) was 167 in the year 2010, whereas the Spanish average was $77.74^{5}$.

Aragon regional government has been designing its RIS3 (Research Innovation Smart Specialisation Strategy) since 2012. Joint initiatives and collaborative issues, such tourism, agrifood and health sectors have been examined with other regional institutions in Navarra and La Rioja. The RIS3 Strategy (2013-2020) enables the identification of specialised knowledge that 
best suits the innovation potential of the region, based on its assets and capabilities. Among other actions, the regional cooperation will be promoted in order to facilitate access to finance, partner search and advanced technological services.

\section{3. $R \& D$ collaborative projects outcomes}

Although planning for R\&D collaborative projects is essential, the success of these projects ultimately depends on how well they are executed (Weck, 2006) in combination with the results (Baccarini, 1999; Munns \& Bjeirmi, 1996). The distinctive characteristic of R\&D projects is grounded on their performance, because the outputs are frequently different from those initially planned. In spite of that, the end results may still be valuable for the firm (UNE166.001, 2006, p. 4).

In the literature, success in alliances is measured by stability, continuity, the evolution of the relationship throughout time and the satisfaction level of partners (Davenport, Davies, \& Grimes, 1999; Mohr \& Spekman, 1994; Mora-valentin et al., 2004). The literature on strategic alliances covers a huge variety of topics, including partners selection, reasons to cooperate, composition, coordination problems, lack of trust and cultural differences, university encouragement, geographical and social distance, public subsidies and R\&D infrastructures, cohesive regional clusters, and the results obtained by firms in alliances (e.g. Adams, Marcu, \& Wang, 2008; Arora \& Gambardella, 1994; Azagra-Caro, Archontakis, Gutiérrez-Gracia, \& Fernández-de-Lucio, 2006; Balachandra \& Friar, 1997; Fleming, King, \& Juda, 2007; Hassink, 1997; lammarino, Piva, Vivarelli, \& Von Tunzelmann, 2012; López, 2008; Miotti \& Sachwald, 2003; Negassi, 2004). Some partners involved collaboration activities that favor a different impact on the outcomes in terms of the range of new knowledge provided to the alliance and in the easiness of accessing to this new knowledge (Un, Cuervo-Cazurra, \& Asakawa, 2010). Nevertheless, the present paper only considers the outcomes regardless of the partners involved, but it includes technological and organisational issues: proprietary benefit, 
technological innovation, continued support to research programs, industrial and intellectual property rights and high-qualified employees' recruitment (Barnes et al., 2006).

\subsection{Managing a R\&D collaborative project}

Cooperation is acknowledged as a mechanism that enables the knowledge transfer and enhances the firm's learning capabilities (Hagedoorn, Link, \& Vonortas, 2000). The AC conceptualization explains the learning process that improves the firm's competitive advantage from external knowledge. According to the literature, this learning process is positively related to the benefits from collaboration (López, 2008). Grant \& Baden-Fuller, (2004) proposed that alliances are primarily used to access knowledge and facilitate the integration of knowledge among partners. However, the AC includes differentiated dimensions: the ability of the firm to value and acquire external knowledge (AC1) forms the potential capability, while the firm's capacity to leverage absorbed knowledge (AC2) and exploit it into innovation (AC3) forms the realized capability of the firms (Arora \& Gambardella, 1994; Cassiman \& Veugelers, 2008; Jansen et al., 2005; Zahra \& George, 2002). According to Lundvall (1997), participant in learning alliances would access some useful know-how from the partners and they would internalize some complementary capabilities and skills possessed by them.

The ability to exploit external information is a critical component of innovation capacity (Lund Vinding, 2006), although this exploration process is a not guarantee of success in the subsequent commercialization (Lichtenthaler \& Lichtenthaler, 2009). Rundquist (2012) pointed out that managers can focus their efforts in order to effectively integrate knowledge in product development projects.

The influence of R\&D project management on project success has been demonstrated in different studies (i.e. Tatikonda \& Rosenthal, 2000). In collaborative projects, management must go beyond each individual company and reach the entire consortium, so the ability to 
transfer best practices is critical to build competitive advantages (Szulanski, 1996) in alliances for several projects or development programs. Accordingly, the ability to identify, negotiate, manage, monitor and configure final collaborations allows firms a capability to learn from selfmanaged partnerships (Feller et al., 2013).

Market orientation is a business culture that reflects the ability of firms to understand and internalize the expressed desires of the customers and then to develop products and services that satisfy those expectations, whereas the latent needs are included in the strategy to anticipate competitors (Slater \& Narver, 1998). The concepts of market orientation and innovation are mutually supportive for strong performance although the links between them have still to be comprehensively examined (Pérez-Luño \& Cambra, 2013).

Empirical studies have found that market orientation is positively related to innovation and competitive advantage, specially in new product development (e.g. Balachandra \& Friar, 1997; Kirca, Jayachandran, \& Bearden, 2005; Narver, Slater, \& MacLachlan, 2004; Pavlou \& El Sawy, 2006; Rundquist, 2012). It also has a positive impact on learning (Santos-Vijande, Sanzo-Pérez, Álvarez-González, \& Vázquez-Casielles, 2005), and it can be used to anticipate and react to the changing environment. Therefore, differences on cooperation performance could be expected as consequence of a responsive or proactive organisation, since anticipation can be a guide for planning collaborative goals (Narver et al., 2004).

Therefore, we propose the following hypotheses:

Hypothesis 1: Absorptive Capacity is positively related to every collaboration outcome:

Hypothesis 1a. AC1 (valuing and acquiring external knowledge acquisition) is positively related to every collaboration outcome.

Hypothesis 1b. AC2 (leveraging absorbed knowledge) is positively related to every collaboration outcome 
Hypothesis 1c. AC3 (exploiting into innovation) is positively related to every collaboration outcome.

Hypothesis 2: Continued support to research programs is positively related to the set-up and execution in project management.

Hypothesis 3: The attainment of a technological innovation is positively related to the market orientation

Hypothesis $3 a$. The attainment of a technological innovation is positively related to the surveillance market orientation

Hypothesis $3 b$. The attainment of a technological innovation is positively related to the responsive market orientation

\section{Testing the determinants of $R \& D$ collaborative project outcomes}

This section describes the methodology, data and the results of the analysis of the R\&D collaborative projects framework.

The quantitative analysis is based on an e-mail survey that was pre-tested with 14 academy and 15 industry experts to validate the integrity and reability of the scales. The survey was delivered between the last quarter of the year 2011 and the first half of 2012. During the first month, 788 firms that had carried out R\&D projects in the 2005-2010 period either alone or with external collaboration were contacted. The population of firms was obtained from the Spanish Technological Development Agency (in Spanish CDTI) which had financed R\&D collaborative projects in the MEV region. We also added to the database the partners of technology transfer projects at the University of Zaragoza (the largest regional research centre) in the period 2005-2007. Only those companies established in the region were incorporated into the database to test the hypotheses. After a contact round, 177 firms of them offered information about their project managers or technical director and the last 
collaborative project evolution. The questionnaires were adddressed to each company's R\&D project manager, and after a third roundup 71 companies returned questionnaires, of which only 69 were valid. Although the response rate $(40.11 \%)$ is not high, it is still a good response rate for a mail survey in our country because Spanish firms are not very used to collaborate in academic studies with universities. Companies are usually reluctant to participate in this kind of studies (Flatten, Greve, et al., 2011; Gartner \& Thomas, 1993; Lefebvre \& Lefebvre, 1992), and sometimes it is even more complicated for them to be involved in critical economic situations like the analysed period when firms were under great financial difficulties and R\&D budget cuts. In spite of that we believe that our sample is representative of the population. We tested for non-response bias by comparing early and late respondents (Armstrong \& Overton, 1977), but we did not find statistically significant differences in the percentage of employees devoted to R\&D activities, the innovation effort and the net profit on sales, indicating that the sample is representative of the population. Besides the data included in the questionnaires, we also interviewed 15 project managers to collect their experiences on R\&D project management. Table 1 provides descriptivie statistics of the main variables used in the models.

Table 1- Descriptive statistics: Firms and Project managers

\begin{tabular}{lllll}
\hline \multicolumn{1}{c}{ FIRMS } & Minimum & Maximum & Average & S.D. \\
\hline Size (number employees) & 0 & 7.34 & 257.57 & 101.35 \\
Export sales (\%) & 0 & 89 & 9.89 & 21.56 \\
Innovation intensiveness & 0 & 1 & 0.65 & 0.48 \\
AC1 & 1 & 7 & 4.67 & 1.49 \\
AC2 & 1 & 7 & 4.85 & 1.50 \\
AC3 & 1 & 7 & 5.18 & 1.59 \\
Responsive Market Orientation & 1.67 & 7 & 5.10 & 1.33 \\
Surveillance Market Orientation & 2 & 7 & 5.22 & 1.47 \\
Collaborative project management & 1 & 7 & 5.29 & 1.26 \\
\hline & & & & \\
PROJECT MANAGERS & & & & \\
\hline Years of experience y R\&D management & 0 & 35 & 10.20 & 8.51 \\
Number of projects directed & 0 & 200 & 16.66 & 27.98 \\
\hline
\end{tabular}


After analysing the information provided by companies and project managers, we run a focus group in June 2014. During the first hour, the study and the quantitative results were presented to participants and the following discussion took another 45 minutes. Data from focus groups are often viewed as secondary in order to complement quantifiable data gathered by using surveys or other research instruments (Kamberelis \& Dimitriadis, 2013). To analyse the information, participants' opinions were collected by using semistructured questionaires and the session was recorded in video. The focus group members belonged to the regional association (AINNA) that has the aim to enhance innovation in the region. The call for attendants was done by the association itself and diffused throughout social networks (Linkedin) and its web site. Participants at the focus group worked in research and technology organisations (five), advanced services in public administration (one) and private companies (one consultant, one start-up entrepeneur, two technological and R\&D managers). Ten participants are an ideal number to manage a focus group (Easton, Easton, \& Belch, 2003). Despite of the subjectivity of the participants (due to their procedence, positively related to collaboration and innovation), the interaction allows researchers not only to discover what people think about a particular topic, but also why they think that way (Morgan, 1988).

The distribution of the sample by firm size indicates that $86.96 \%$ are SMEs and $13.04 \%$ are large companies ${ }^{6}$. The main industries involved in our study are low-technology (52.17\%) although high-technology industries are also well represented (31.88\%). Firms in peripheral regions can benefit from the proximity of, and good communications with, adjoining central regions (Martínez-Sánchez, 1992); in our study those central regions are Madrid and Catalonia. 


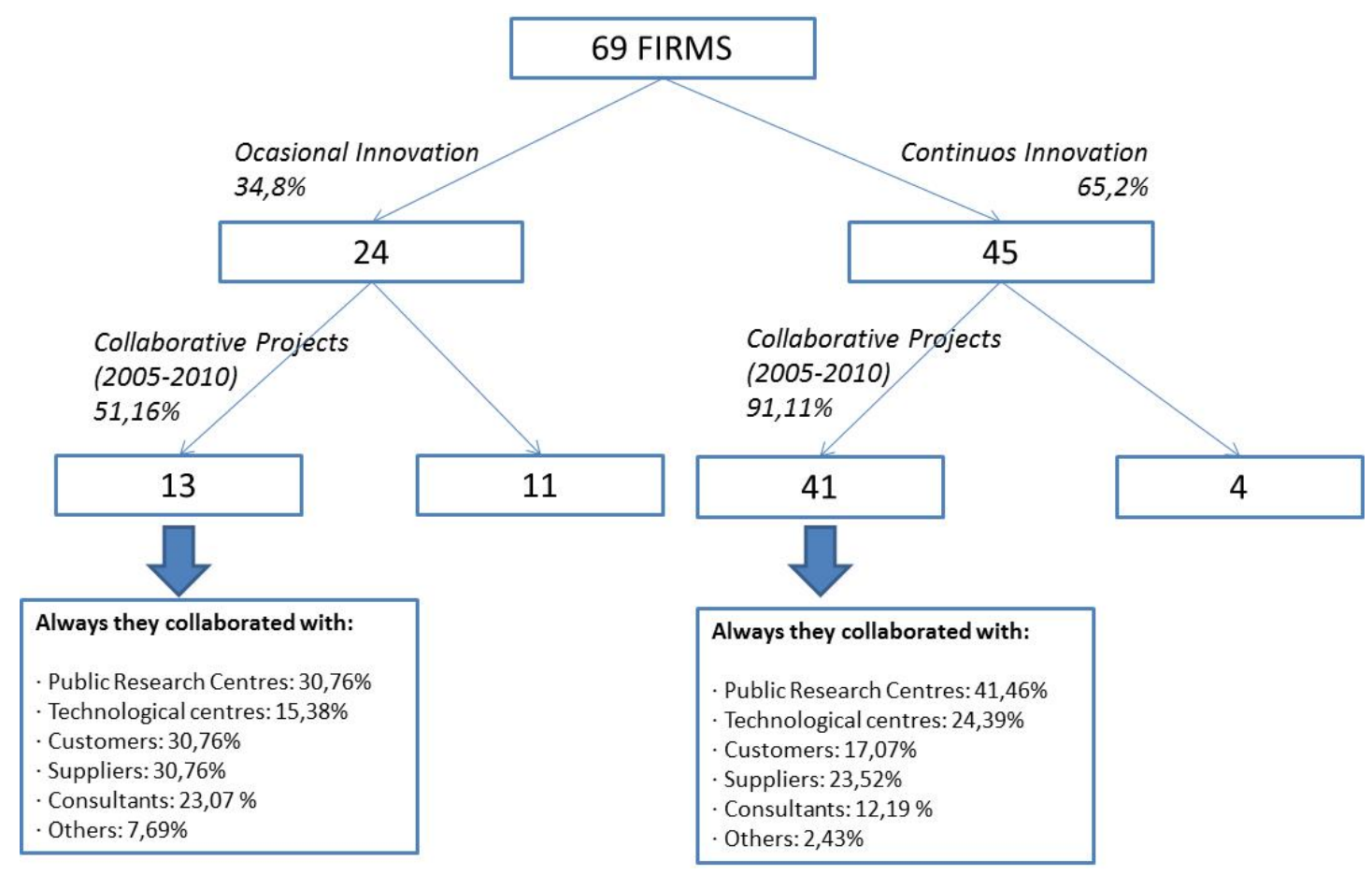

The collaboration strategy of the firms (figure 1 ) shows that the $65.2 \%$ of firms that cooperate in R\&D activities develop continous innovation and $92.75 \%$ has executed projects in the 2005 2010 period. Vertical collaboration (with Public Research Centres and Technological centres) is always developed in more than $30 \%$ of the projects. Firms which develop ocasional innovation have always a greater horizontal collaboration than continous innovation developers $(30.76 \%$ with clients and suppliers in ocasional versus $17.07 \%$ with customers, and $23.52 \%$ with suppliers in continous).

Table 2 shows the collaboration outcomes from the last R\&D project in the interviewed firms. Technological innovation is the most frequent result $(88.89 \%)$ but it is only significant in chisquare tests for high-technology firms. In medium-technology firms, continued support to research programs is a significant result of the collaboration project. The recruitment of highly 
qualified employees is greatly significant, both for high-technology firms (58.33\%), and lowtechnology firms (29.17\%).

The outcomes in firms with R\&D department involved in the project show significate differences. Therefore, $61.11 \%$ of firms which an active R\&D department has obtained a technological innovation and recruited qualified employees at $90 \%$ and $95 \%$ of significance.

Table 2- Last R\&D collaborative project outcomes

\begin{tabular}{|c|c|c|c|c|c|c|}
\hline \multirow{2}{*}{ OUTCOMES } & \multicolumn{5}{|c|}{ SECTOR: technology intensiveness } & \multirow{2}{*}{$\begin{array}{c}\text { R\&D } \\
\text { Department }\end{array}$} \\
\hline & & High & Medium & Low & Total & \\
\hline Technological innovation & $88.89 \%$ & $37.50^{\star}$ & 18.75 & 43.75 & $100 \%$ & $61.11 * \%$ \\
\hline Proprietary benefit & $77.78 \%$ & 35.71 & 19.05 & 45.24 & $100 \%$ & $82.35 \%$ \\
\hline $\begin{array}{l}\text { Continued support to research } \\
\text { programs }\end{array}$ & $74.07 \%$ & $40.00^{*}$ & $15.00^{*}$ & 45.00 & $100 \%$ & $46.29 \%$ \\
\hline Patents/IPR & $29.63 \%$ & 43.75 & 12.50 & 43.75 & $100 \%$ & $37.14 \%$ \\
\hline $\begin{array}{l}\text { High qualified employees } \\
\text { recruitment }\end{array}$ & $44.44 \%$ & $58.33^{\star \star \star}$ & 12.50 & $29.17^{\star \star}$ & $100 \%$ & $54.28 * \star \%$ \\
\hline
\end{tabular}

Notes: Chi-square test is ${ }^{*} p<0.1 ;{ }^{* *} p<0.05 ;{ }^{* *} p<0.01$

The ten project management practices considered to manage and set-up the projects in the study (Barnes et al., 2006) can be mapped graphically on a spider-chart (Chart 1). Highcollaborative firms (above average in vertical and horizontal collaboration) use more frequently every managerial practice (grade of use of every one is from $1=$ 'never used' to 7='always used'). The partnerships between firms and research and technology centres (institutional collaboration) show a clearer definition of the responsibilities and the management for a mutual benefit. The partnerships between firms and their customers, suppliers and consultants (vertical collaboration) are less management-intensive than institutional collaboration in general. 


\section{Chart 1. Project management and partnership}

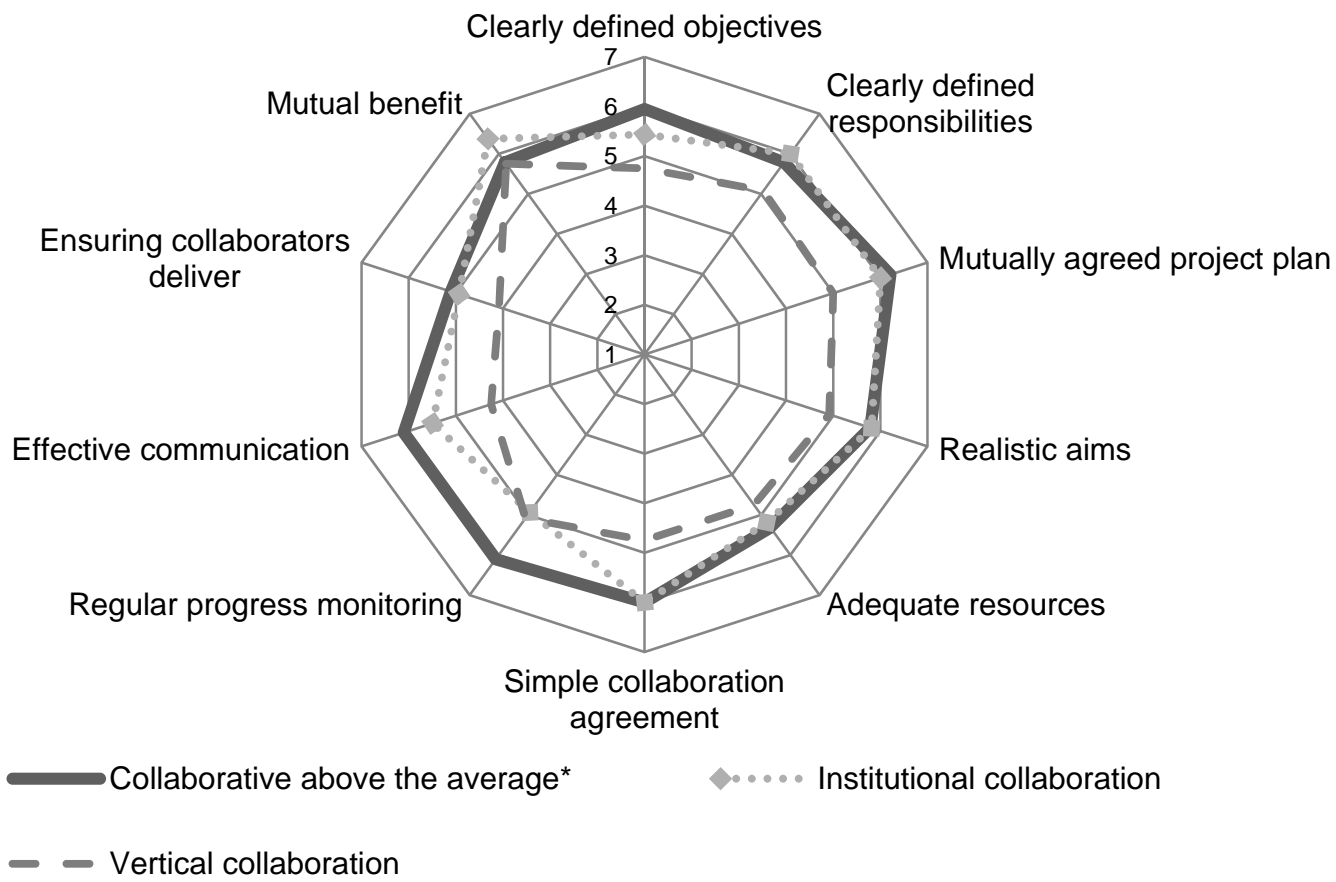

*vertical and institutional

\subsection{Test design}

Different statistical analyses have been carried out to test our research framework. Dependent variables are based on the outcomes of the practical management tool developed by Barnes et al., (2006), which are equal to 1 if there are positive and 0 if they were not obtained in the last R\&D collaborative project. The same set of independent variables is used to test the different hypotheses and they were constructed from validated scales of previous studies. This design results in a set of logit specifications, which allows a clearer interpretation of the influence of different independent variables. According to the nature of the dependent variable, logistic regressions were run for each collaborative outcome, and linear regressions for each AC phase.

The construction and use of the dependent, independent and control variables are explained in table 3 . The independent variables are the collaborative project management, the three $A C$ 
phases and the market orientation whereas the unit of analysis is the firm. The baseline assumption in this paper is that collaborative practices to manage the R\&D collaboration is a construct, the organisational $\mathrm{AC}$ are three constructs, and market orientation are two constructs that include the responsive actuation (i.e. obtaining a technological innovation in a market-pull scheme) and the surveillance (i.e. supporting previous R\&D programs in a technology-push development).

Barnes et al. (2006) presented the practices to set-up and execute a project and we have included the relevant practices and validated a scale to measure the joint use of them throughout nine items in preliminary selection (according to De Vellis's (2003) suggestions). They were validated with the collaboration of 29 experts who were consulted about the integrity and validity of the questionaire. The experts reviewed the inclusion of validation items and helped to determine the format measurement, which was an ordinal scale between 1 ('totally disagree') and 7 ('totally agree') about the degree of use of Barnes et al's practices to manage a collaborative project; They agreed to keep fifteen items but eventually only nine items were included, and one of them was eliminated after the exploratory factor analysis (see table 3 ). This was validated for the eight items, and the integrity was higher than the recommended value (Cronbach's alpha over 0.7 ).

Each AC dimension is represented by a variable that is measured with multi-item scales derived from previously validated studies (Flatten, Engelen, Zahra, \& Brettel, 2011; Narver et al., 2004). Each item was rated on a Likert scale from 1 ('never used') to 7 ('always used') for AC and grade of effectivity in comparison to competitors, whereas for market orientation the scale ranged from 1 ('very low') to 7 ('very high'). The item scales were validated by using principal component factor analysis for a unidimensional construct (EFA and CFA). The Kaiser-Meyer-Olkin values of all measures are higher than the recommend value of 0.60 (Kaiser, 1974) and the Barlett's Test of Sphericity was statistically significant at the $1 \%$ level (Barlett, 1954). Both tests passed by all constructs indicates that our data is adequate for the analysis. In order to assess the internal 
consistency of scales, we use Cronbach's alpha and the common threshold value of 0.70 is applied (Nunnally, 1978). Table 4 shows that all Cronbach's alpha values are acceptable.

We include firm size (log) as control variable because most empirical studies indicate that it is positively related to the propensity to co-operate in R\&D (Bayona, García-Marco, \& Huerta, 2001; Fritsch \& Lukas, 2001). The rest of control variables are positively related to innovation outputs in prior studies: innovation effort (Stock, Greis, \& Fischer, 2001; Tsai, 2001) and export intensity (Cassiman, Golovko, \& Martínez-Ros, 2010). Our study also includes the intensiveness of innovation as a dummy variable (0 for occasional and 1 for continuous). 


$\begin{array}{cl}\text { Dependent variables: } \\ \text { Collaborative } & \text { - Technological innovation } \\ \text { outcomes } & \text { Proprietary benefit } \\ & \text { - Patinued support to research programs } \\ & \text { - High qualified employees recruitment }\end{array}$

\section{Independent variables: Grade of use}

Absorptive $\quad$ 1. The search for relevant information concerning our industry is every-day business in our company

Capacity $\quad 3$. Our management expects that the employees deal with information beyond our industry

4. In our company ideas and concepts are communicated cross-departmental.

6 . In our company there is a quick information flow, e.g., if a business unit obtains important information it communicates this information promptly to all other business units or departments

7. Our management demands periodical cross-departmental meetings to interchange new developments, problems, and achievements

8. Our employees have the ability to structure and to use collected knowledge

9. Our employees are used to absorb new knowledge as well as to prepare it for further purposes and to make it available

10. Our employees successfully link existing knowledge with new insights

11. Our employees are able to apply new knowledge in their practical work

12. Our management supports the development of prototypes
13. Our company regularly reconsiders technologies and adapts them accordant to new knowledge

14. Our company has the ability to work more effective by adopting new technologies

Market

orientation

1. We spend considerable time reading trade publications and magazines, respect the competitors

Surveillance

2. We frequently scan the environment to identify new business opportunities, respect the competitors

Market

Orientation

Responsive
3. We are quick to discuss changes in our customers' product preferences, respect the competitors

4. We devote a lot of time implementing ideas for new products and improving our existing products, respect the competitors

5. We are quick to respond to significant changes in our competitors' pricing structures, respect the competitors
$\mathrm{KMO}=0.891$

Sphericity-

Barlett $=742.12^{\star \star *}$

Variance

explained $=74.55 \%$

Items 1and 12 eliminated

Confirmatory Analysis (3

factors):

Variance

explained $=78.68 \%$

$\mathrm{KMO}=0.67$

Barlett $=79.77^{\star \star \star}$

Variance explained

$(5)=70.21 \%$ 


\begin{tabular}{|c|c|c|}
\hline & Description & Factorial Analysis \\
\hline $\begin{array}{l}\text { R\&D } \\
\text { colaborative } \\
\text { project } \\
\text { management } \\
\text { (set up and } \\
\text { execution) }\end{array}$ & $\begin{array}{l}\text { 1. Clearly defined objectives } \\
\text { 2. Clearly defined responsabilities } \\
\text { 3. Mutually agreed project plan } \\
\text { 4. Realistic aims } \\
\text { 5. Adequate resources } \\
\text { 6. Regular progress monitoring } \\
\text { 7. Effective communication } \\
\text { 8. Ensuring collaborators deliver } \\
\text { 9. Mutual benefit }\end{array}$ & 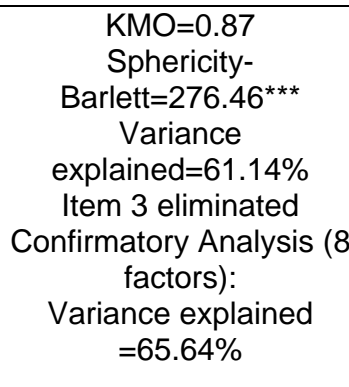 \\
\hline \multicolumn{3}{|l|}{ Control: } \\
\hline $\begin{array}{l}\text { Firm size } \\
\text { Innovation effort } \\
\text { Innovation } \\
\text { intensiveness } \\
\text { Export intensity }\end{array}$ & $\begin{array}{l}\text { Number of employees (in log) } \\
\cdot \\
\text { - R\&D Spending (€)/Sales( } € \text { ) (year 2010) } \\
\text { - Dummy: 0- Ocassional innovation; 1-Continous innovation } \\
\text { - Ratio of exports to sales (2010) }\end{array}$ & \\
\hline
\end{tabular}

Notes: Exploratory analysis and confirmatory if any item is elimited to increase the reability. KMO: Kaise-Meyer-Olkin test value. Spehericity Barlett test (chi-rounded) ***p<0.01. Variance explained 
Table 4- Descriptive statistics: means, standard deviations, correlations (Spearman's Rho) and Cronbach's alpha (in bold and italics)

\begin{tabular}{|c|c|c|c|c|c|c|c|c|c|c|c|c|c|c|c|}
\hline & & Mean & SD & 1 & 2 & 3 & 4 & 5 & 6 & 7 & 8 & 9 & 10 & 11 & 12 \\
\hline 1 & R\&D Collaborative outcomes & 3.17 & 1.20 & & & & & & & & & & & & \\
\hline 2 & Technological innovation & 0.89 & .032 & $.340^{\star \star}$ & & & & & & & & & & & \\
\hline 3 & Continued sup. programs & 0.74 & 0.44 & $.564^{\star \star}$ & -.075 & & & & & & & & & & \\
\hline 4 & Firm size & 257.57 & $1,019.35$ & .011 & -.104 & -.020 & & & & & & & & & \\
\hline 5 & Export intensity & 0.32 & 0.07 & .199 & -.011 & .079 & .173 & & & & & & & & \\
\hline 6 & Innovation effort & 0.65 & 0.205 & $.500^{\star \star}$ & $3.52^{\star *}$ & $.260^{\star}$ & -.096 & .071 & & & & & & & \\
\hline 7 & R\&D col. project management & 4.36 & 2.033 & .183 & .223 & $.301^{\star}$ & -.024 & -.192 & $.296^{\star}$ & 0.919 & & & & & \\
\hline 8 & $\mathrm{AC} 1$ & 5.29 & 1.26 & $-.309^{\star}$ & .220 & $.21^{*}$ & -.123 & -.030 & $.237^{\star}$ & $.398^{\star *}$ & 0.911 & & & & \\
\hline 9 & $\mathrm{AC} 2$ & 5.10 & 1.33 & .112 & .154 & .127 & $-.293^{\star \star}$ & -.102 & .178 & $.289^{*}$ & $.666^{\star *}$ & 0.907 & & & \\
\hline 10 & AC3 & 5.22 & 1.47 & $.397^{\star \star}$ & $.282^{\star}$ & $.338^{\star}$ & -.190 & -.001 & $.297^{\star \star}$ & .205 & $.685^{\star \star}$ & $.689^{\star \star}$ & 0.889 & & \\
\hline 11 & Surveillance Market Orientation & 5.18 & 1.59 & .133 & $.276^{*}$ & .081 & $-.207^{\star}$ & .081 & .142 & .212 & $.336^{* \star}$ & $.332^{* *}$ & $.409 *$ & .772 & \\
\hline 12 & Responsive Market Orientation & 4.67 & 1.49 & $.241^{\star}$ & $.254^{\star}$ & $-.250^{\star}$ & .097 & $-.250^{*}$ & $.209^{\star}$ & .074 & $.451^{\star \star}$ & $.451^{\star \star}$ & $.425^{\star \star}$ & $.371^{\star *}$ & 0.648 \\
\hline
\end{tabular}

Notes: ${ }^{*} p<0.1 ;{ }^{*} p<0.05$ 


\subsection{Survey results}

The quantitative research explores the relationship between the $A C$, market orientation and collaboration management with the R\&D results. We carried out two logistic and a linear regression (table 5 shows the results), since this methodology is, generally, suitable for identifying the effects of the behavior of explanatory variables (independent) on the behavior of explained (dependent).

First of all, we should highlight that the results are driven by the $A C$, although not all $A C^{\prime} s$ dimensions are relevant for every collaboration outcome. Following the theoretical expectations described in Hypothesis 1c, the absorptive capacity to exploit the external knowledge into innovation (AC3) is positively related to the continued support to research programs $(p<0.1)$ and to the general outcomes $(p<0.01)$ indicating a positive impact on the firms' likelihood to enhance their collaborative results if they increase their AC3. The significant beta-coefficient allied to Hypothesis $1 b(\beta=-0.30 ; p<0.1)$ confirms that the capacity to leverage the absorbed knowledge (AC2) is negatively related to the collaboration outcomes.

The second hypothesis was that the influence of the set-up and the execution management according to best practices were positively related to the outcomes. It was supported when the project belonged to a program or it continued with ongoing research $(\beta=-0.76 ; p<0.05)$.

Finally, the third hypothesis was the positive relationship between market orientation and the outcomes. This is supported when the R\&D collaborative project attains a technological innovation as a consequence to respond the customer demands $(\beta=1.75 ; p<0.05)$.

Regarding the control variables, innovation effort and export intensity are positively related to collaboration outcomes whereas firm size is not significantly related. 
Table 5. Logistic regressions: (1) Technological Innovation (2) Continued support to research programs. Linear regression of collaboration outcomes (3)

\begin{tabular}{|c|c|c|c|}
\hline \multicolumn{4}{|l|}{ Model } \\
\hline & $\begin{array}{l}\text { Technological } \\
\text { innovation (1) }\end{array}$ & $\begin{array}{l}\text { Continued } \\
\text { support (2) }\end{array}$ & $\begin{array}{l}\text { Collaboration } \\
\text { outcomes (3) }\end{array}$ \\
\hline \multirow{2}{*}{ Firm size } & -0.001 & 0.001 & -0.055 \\
\hline & $(0.173)$ & $(0101)$ & $(0.446)$ \\
\hline \multirow{2}{*}{ Export intensity } & -0.041 & 0.029 & $0.276^{\star \star}$ \\
\hline & $(1.073)$ & $(0.879)$ & $(2.095)$ \\
\hline \multirow{2}{*}{ Innovation effort } & $2.945^{\star}$ & 0.740 & $2.285^{\star \star}$ \\
\hline & $(2.931)$ & $(0.654)$ & $(2.367)$ \\
\hline \multirow{2}{*}{ AC1 } & & 0.199 & -0.05 \\
\hline & & $(0262)$ & $(0.29)$ \\
\hline \multirow{2}{*}{ AC2 } & & -0.327 & -0.305 \\
\hline & & $(0.630)$ & $(1.904)^{\star}$ \\
\hline \multirow{2}{*}{ AC3 } & & $0.246^{*}$ & $0.414^{\star \star}$ \\
\hline & & $(2.967)$ & $(2.801)$ \\
\hline R\&D colaborative project & & $0.761^{\star \star}$ & \\
\hline management & & $(4.986)$ & \\
\hline \multirow{2}{*}{ Surveillance Market Orientation } & 0.876 & & \\
\hline & $(2.407)$ & & \\
\hline \multirow{2}{*}{ Responsive Market Orientation } & $1.752^{\star \star}$ & & \\
\hline & $(4.117)$ & & \\
\hline Log-likehhod & 18.944 & 42.456 & \\
\hline $\mathrm{R}^{2}$ - Cox \& Schnell & .292 & 0.298 & \\
\hline $\mathrm{R}^{2}$ - Nagelkerke & 0.582 & 0.432 & \\
\hline $\begin{array}{l}F \text { (Full modell) } \\
\text { Adjusted } R^{2}\end{array}$ & & & $\begin{array}{l}5.663^{\star \star \star} \\
0.422\end{array}$ \\
\hline
\end{tabular}

Notes: Beta coefficients are in (1) Technological Innovation and (2) Continued support to research programs. They are: ${ }^{*} p<0.1 ;{ }^{*} p<0.05$. Wald statistics are given in parenthese. Beta coefficients are in (3) Collaboration outcomes. Standarized significant beta coefficients are: ${ }^{*} p<0.1 ;{ }^{* \star} p<0.05$, and ${ }^{* \star *} p<0.01$. and $t$-values

\subsection{Focus group results}

The interviewed project managers agreed with the literature about AC and innovation results.

They established a positive relationship between every AC dimension and the project outcomes, which indicates that firms either collaborate or outsource the R\&D. The focus group discussion on this topic contributed with a clarifying distinction about the nature of collaboration, and this is based on the AC2: the contribution to the partnership to transform the acquired knowledge. 
A - 'The difference between partnership and outsourcing lies in the expected outcome, partners could teach to the other partners how to integrate what they have obtained. The collaboration must provide the firm something more than (pause 2 seconds) a deliverable ${ }^{7}$

\section{(Research and Technology Organisation 1, R\&D Manager)}

Managers with experience in collaborative projects acknowledged the public subsidies. Some managers usually ask for them in every R\&D project; even though they could finance the projects without public support. This behavior is counterproductive to establish stable alliances and real collaborative R\&D projects because every partner supports new developments at the same time that they have opportunities to get a benefit. Firms in this context have multiple projects with subcontracted partners. Thus collaboration is unreal and it would conceal a R\&D acquisition.

B - 'We have had many projects such as $\mathrm{PROFIT}^{8}$, Cheque Tecnológico $^{9}$...). It was always a

budget item for outsourcing technology centers but if you establish this difference between collaborating and outsourcing, it seems to me odd that there are companies willing to collaborate in projects.' (Firm 2, R\&D Manager)

Likewise, the negative relationship between AC2 and the project outcomes indicates that firms with capability to transform the external knowledge could not be interested in R\&D cooperation. Maybe, it could be a corporative culture topic, either to have not capacity to transform the knowledge (AC2) or to have capacity to exploit it (AC3) without a partnership.

C - 'Not that anyone needed to develop innovations, the reason is that I do not want to share the benefit. Sometimes we are very shortsighted.' (Firm 2, R\&D Manager)

Thereby firms with AC2 would have no interest to form R\&D partnerships because they could access to new knowledge and transform to use it internally alone. However the loss of opportunities to access new knowledge has been acknowledged by firms in the focus group. The lack of support for Hypothesis 1a could be interpreted like this: the managers were not able to find new knowledge for the project except when they were focused on the customer (responsive market orientation). Thus, Hypothesis 3a. is not supported because the short-term vision makes 
firms don't pay attention to the surveillance, either in the future needs of their customers or in the needs of potential and new customers.

D -'I'm hearing and I have identified unfilled capabilities due to not finding options that fill them. [...] The company wants to solve a problem, to have a product (pause 3 seconds) and put it on the market. A small business does not see a channel to output these situations.'

(Firm 1, R\&D Manager)

National and regional programs eventually support different kind of firms, their subsidies have different policy goals, and they promote the collaboration in all OECD countries (Blanes \& Busom, 2004). However, sharing the results of the project between partners with no-profit purposes presents a new cross-cultural challenge.

E - 'The last call of the Government of Aragon to public-private partnership model agreement which provided research centers participating in the exploitation of results was established.

[...] There was a clash of cultures when companies viewed that public agencies would have a future profit from these results. [...] At the end SMEs think that the effectiveness of their sales is getting results while the university does nothing'. (Firm, Consultant)

Most of the firms collaborated continuously and their outcomes were acknowledged (see table 1). Although prior research showed that small firms tend to cooperate in the regional environment more than big companies (among others Arancegui, 2002; Miotti \& Sachwald, 2003), the present study has not found significant firm-size differences.

However, the recruitment of high-qualified employees is the least cited outcome and the focus group valued the quantitative results within the context of the business culture of the region. A 'real' collaboration perhaps should include more relations between partners than those included in this study, either formalized with a formalized consortium or based only on social and personal relations. There are new forms of collaboration that are not based on economic considerations to start the activities. 
F - 'We are working at risk: a contract stipulates the responsibilities and the kind of works to do without charging anything for now for every partner. It would be (payments) depending on things such as a percentage of sales, etc. we will recover the investment itself now that it has been valued at ' $x$ '. [...] The problem will be controlling resources, such as the adequacy of man / hours of project' (Firm, Entrepreneur)

G - 'We have a case that as a result of a collaborative project between a federal agency and a company, they have created a spin-off owned $50 \%$ by providing the infrastructure and capital resources when the benefit will go to the new company to start your career in a very innovative product. [...] For this reason, flexibility and meeting your traveling companion is a must.' (Firm, Consultant)

New frameworks to design a consortium agreement, as suggested above, include, among others, the reconsideration of the ways to manage the partnership. Managerial practices aimed specifically to R\&D collaboration influence the continued support to research programs at $95 \%$ level of significance, according to Hypothesis 2. The interviewed practitioners had not a special interest in this issue because they consider that project management already includes relationships with stakeholders. Among others, contract and consortium agreements, responsibilities definition, resources planning, and communication are managerial practices within the praxis (Project Management Institute, 1987). The focus group discussion showed agreement with all the hypotheses of our study although they also pointed out the importance of firm size in their regional context; there is no need to manage the collaboration in a different manner than the ongoing project because the research team should be small and relatively stable along time. According to Hypothesis 2, managerial practices affect positively the support to research programs.

Market orientation as response to customer expectations is positively related $(p<0.05)$ to obtain technological innovation, which supports Hypothesis $3 \mathrm{~b}$ and prior research about new product 
development. Although everybody agreed during the interviews about the importance to attend the latent needs of customers, there is a low degree of marketing surveillance use inside the firms. That is the reason why quantitative analysis could help show the reality of the region: the innovation is only customer-responsive and it is embodied in a new technological innovation. Focus-group discussion was directed to the qualifications of general managers at the regional firms and their attitudes toward technological change, in as much as they should innovate if there is no other alternative and their perspective should be short-term oriented (see comments C, D, and $\mathrm{E})$.

\section{Discussion and conclusions}

In this paper an integrated framework is researched to enhance the results of the R\&D collaborative projects by paying attention to the regional level at the same time. The first hypothesis was that the absorptive capacity of knowledge could be able to enhance the outcomes in R\&D collaborative projects, although the results point out the need to further analyze each dimension separately. Thereby the capacity to exploit the external knowledge for commercial use is decisive to improve the results of the collaboration, while the capacity to acquire is not statistically significant. As a remarkable finding, firms which have a lack of capacity for transforming the knowledge could get outcomes in R\&D projects due to collaboration.

Prior studies showed that R\&D cooperation, external knowledge acquisition and experience with knowledge-search could be key antecedents of a firm's potential absorptive capacity (Fosfuri \& Tribó, 2008). In regional context the absorptive capacity has played a relevant rol in R\&D cooperation (Negassi, 2004). According to several authors (i.e. López, 2008; Miotti \& Sachwald, 2003; Muscio, 2007), absorptive capacity has a relevant impact on the probability to cooperate and to establish collaborations with external organisations in the context of open innovation. The current study is consistent with previous research and it shows that absorptive capacity could 
enhance the outcomes of the R\&D collaborative project. However, the distinction between collaboration and outsourcing is relevant for the contribution to assimilate new external knowledge. It has been probed that the R\&D department is particularly important to obtain and integrate knowledge from public research organisations for product innovation, although R\&D activities are considered as a primary source of absorptive capacity (Bogers \& Lhuillery, 2011). The significative results to allign the recruitment of high-qualified personnel with the development of technological innovations that we have found in our study show the importance to have a specialized area inside the firm to carry out innovation projects.

Government policy has further encouraged firms to develop collaborative projects by providing tax incentives and special funding programs that require mixed partnership as a funding condition. Regionalization and decentralization are concurrent trends that also affect the science and technology policies, and Spanish regional authority's interventions are much more diverse than the predominant view around the convergence or sub-national innovation policies (SanzMenéndez \& Cruz-Castro, 2005). Because our results show that a real collaboration should be based on the access to new knowledge when firms are not capable to integrate it in their innovation process, innovation policies should consider the synergies between the partners. Likewise they should foster the development of small-world structures (Fleming et al., 2007) to avoid lost opportunities to innovate related to potential capacity. Collaborative networks have probed their decisive importance, as well as regional resources for accessing tacit and codified knowledge (Asheim \& Isaken, 2002). Exploration-exploitation trade-off is well acknowledged in innovation environment, them public policy should try to ensure that a balance between the two in the industrial system. Among the policy options are keeping technological rivalry open by supporting alternatives, introducing diversity in the industry by supporting the entry and survival of new firms (specially SMEs), and supporting variety through a common infrastructure (standardization and norms) and better dissemination of codified information (Malerba \& Orsenigo, 1997). The Middle Ebro Valley regional policies since 2008 and especially from the year 
2014 are aligned with this new vision: entrepreneurs find a good breeding ground for creating and, especially, finding private resources based on collaborative knowledge.

Market intelligence (surveillance) is related not only to current needs, but also to future needs as well (Kohli \& Jaworski, 1990). Even though the adoption of market-orientation strategies requires resources, it generates growing revenues and profits in spite of its implementation costs (Kirca et al., 2005). The anticipation could provide new customers or a privilege position on the market, it could be associated with the technology strategy design, and consequently with the new knowledge to accomplish an innovation. The results support that exploiting knowledge is the key to improve R\&D outcomes. Nevertheless, the source and nature of external knowledge should be identified, accessible, and appropriable by firms in advance. Cross-cultural issues are acknowledged barriers to innovation policies and networks.

Unless the characteristics of R\&D alliances have been changed along time (Tomasello, Napoletano, Garas, \& Schweitzer, 2013), our results evidence the relevance to manage the collaborative project throughout an innovation program and also in the long-term (Davenport et al., 1999). Trust in partners and the flexibility of cooperative agreements are boosting R\&D projects, even with finance restriction, throughout the creation of new cooperation ways. A filter between knowledge and regional economic growth was pointed out by Acs \& Plummer (2005) which could be reduced by new ventures. These forms of R\&D cooperation are directed to exploit the knowledge in a more efficient way; thus firms are adapting their technological strategies to the changing environment. Likewise, it has been underscored as one of the main reasons for their growing development since the 1980s (Ciborra, 1991; Kogut, 1988). Our results are aligned to Bayona, García-Marco, \& Huerta (2001), they showed that Spanish firms need to have certain internal capabilities in R\&D to undertake cooperative innovation projects.

By checking the usefulness of a scale to measure how well most common activities related to setup and execution of a collaborative R\&D project (based on Barnes et al., 2006), we have provided 
a new academic indicator for this topic. It considers the practices to run R\&D collaborative projects and our results show the importance to paying much more attention to them if there is a program to continue the partners' innovations.

Several limitations of this study need to be noted. First, the small size of the sample and the crosssectional nature of the study would require further replication by other empirical studies. For instance, it would be useful to use longitudinal measures of absorptive capacity and collaborative results as consequence of a virtuous circle among them, and/or with the knowledge-stock formation (del Carmen Haro-Domínguez, Arias-Aranda, Javier Lloréns-Montes, \& Ruíz Moreno, 2007). Thus it would be possible to expand our measure of absorptive capacity to include the possibility of adopting an active surveillance of the market, foresight initiatives (with or without external support) by other organisations. The second limitation of our study is the measure of outcomes in general conclusions. Due to difficulties of finding primary sources, the research design had to ignore information from other outcomes nature, such as the origin of a joint venture or a crowd-funding project. These results could provide additional information about how their leadership, management and entrepeneurship style.

Despite its limitations, the study offers important insights for the field of regional innovation and access to external knowledge. Future research along these lines might establish whether each dimension of absorptive capacity has a different impact on each innovation result and the joint effect 'to do' and 'to learn' in R\&D which is of increasing importance for firms dealing in the open innovation arena. 


\section{References}

Acs, Z. J., \& Plummer, L. a. (2005). Penetrating the "knowledge filter" in regional economies. The Annals of Regional Science, 39(3), 439-456. doi:10.1007/s00168-005-0245-x

Adams, J. D., Marcu, M., \& Wang, a. J. (2008). Public Technology Infrastructure, R\&D Sourcing, and Research Joint Ventures. Economics of Innovation and New Technology, 17(7-8), 631-648. doi:10.1080/10438590701785561

Arancegui, M. N. (2002). La cooperación para la innovación en la empresa española. Economia Industrial, 346, 47-66.

Arbussà, A., \& Coenders, G. (2007). Innovation activities, use of appropriation instruments and absorptive capacity: Evidence from Spanish firms. Research Policy, 36(10), 1545-1558. doi:10.1016/j.respol.2007.04.013

Armstrong, J. ., \& Overton, T. (1977). Estimating Non-Response Bias in Mail Surveys. Journal of Marketing, 14(3), 396402.

Arora, A., \& Gambardella, A. (1994). Evaluating technological information and utilizing it. Journal of Economic Behavior \& Organization, 24(1), 91-114. doi:10.1016/0167-2681(94)90055-8

Asheim, B., \& Isaken, A. (2002). Regional Innovation Systems: The Integration of Local "Sticky" and Global "Ubiquitous" Knowledge. The Journal of Technology Transfer, 27(1), 77-86.

Azagra-Caro, J. M., Archontakis, F., Gutiérrez-Gracia, A., \& Fernández-de-Lucio, I. (2006). Faculty support for the objectives of university-industry relations versus degree of R\&D cooperation: The importance of regional absorptive capacity. Research Policy, 35(1), 37-55. doi:10.1016/j.respol.2005.08.007

Baccarini, D. (1999). The logical framework method for defining project success. Project Management Journal, 30(4), 25-32.

Bakker, R. M., Cambré, B., Korlaar, L., \& Raab, J. (2011). Managing the project learning paradox: A set-theoretic approach toward project knowledge transfer. International Journal of Project Management, 29(5), 494-503. doi:10.1016/j.ijproman.2010.06.002

Balachandra, R., \& Friar, J. H. (1997). Factors for Success in R\&D Projects and New Product Innovation: A Contextual Framework. IEEE Transactions on Engineering Management, 44(3), 276-287.

Barlett, J. R. (1954). A note for multiplying factors for various chi square approximations. J. R. Stat. Soc., 16, $296-298$. Retrieved from http://scholar.google.com/scholar?as_q=\&as_epq=\&as_oq=\&as_eq=\&as_occt=any\&as_sauthors=Barlett\&as_publicatio

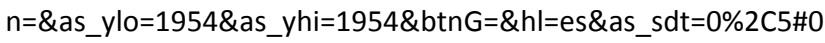

Barnes, T. A., Pashby, I. R., \& Gibbons, A. M. (2006). Managing collaborative R\&D projects development of a practical management tool. International Journal of Project Management, 24, 395-404. doi:10.1016/j.ijproman.2006.03.003

Bayona, C., García-Marco, T., \& Huerta, E. (2001). Firms' motivations for cooperative R\&D: An empirical analysis of Spanish firms. Research Policy, 30(8), 1289-1307. doi:10.1016/S0048-7333(00)00151-7

Becker, W., \& Dietz, J. (2004). R\&D cooperation and innovation activities of firms-evidence for the German manufacturing industry. Research Policy, 33(2), 209-223. doi:10.1016/j.respol.2003.07.003

Benner, M., \& Tushman, M. (2015). Reflections on the 2013 Decade Award: "Exploitation, Exploration, and Process Management: The Productivity Dilemma Revisited " ten years later Reflections on the 2013 Decade Award: " Exploitation, Exploration, and Process Management : The Producti. Academy of Management Review, Published(4), 136.

Beugelsdijk, S. (2009). The Regional Environment and a Firm's Innovative Performance: A Plea for a Multilevel Interactionist Approach. Economic Geography, 83(2), 181-199. doi:10.1111/j.1944-8287.2007.tb00342.x

Biedenbach, T., \& Müller, R. (2012). Absorptive, innovative and adaptive capabilities and their impact on project and project portfolio performance. International Journal of Project Management, 30(5), 621-635. 
doi:10.1016/j.ijproman.2012.01.016

Bigliardi, B., \& Galati, F. (2013). Models of adoption of open innovation within the food industry. Trends in Food Science and Technology, 30(1), 16-26. doi:10.1016/j.tifs.2012.11.001

Blanes, V., \& Busom, I. (2004). Who participates in R\&D subsidy programs? The case of Spanish manufacturing rms. Research Policy, 33, 1459-1476. doi:10.1016/j.respol.2004.07.006

Bogers, M., \& Lhuillery, S. (2011). A Functional Perspective on Learning and Innovation: Investigating the Organization of Absorptive Capacity. Industry \& Innovation. doi:10.1080/13662716.2011.591972

Bonaccorsi, A., \& Piccaluga, A. (1994). A theoretical framework for the evaluation of university-industry relationships. $R \& D$ Management, 24(3), 229-247. doi:10.1111/j.1467-9310.1994.tb00876.x

Camisón, C., \& Forés, B. (2010). Knowledge absorptive capacity: New insights for its conceptualization and measurement th. Journal of Business Research, 63(7), 707-715. doi:10.1016/j.jbusres.2009.04.022

Carlsson, B. (2006). Internationalization of innovation systems: A survey of the literature. Research Policy, 35, 56-67. doi:10.1016/j.respol.2005.08.003

Cassiman, B., Golovko, E., \& Martínez-Ros, E. (2010). Innovation, exports and productivity. International Journal of Industrial Organization, 28(4), 372-376. doi:10.1016/j.ijindorg.2010.03.005

Cassiman, B., \& Veugelers, R. (2000). External Technology Sources: Embodied or Disembodied Technology Acquisition. SSRN Electronic Journal, (January), 1-22. doi:10.2139/ssrn.224582

Cassiman, B., \& Veugelers, R. (2008). R \& D Cooperation and Spillovers : Some Empirical Evidence from Belgium. The American Economic Review, 92(4), 1169-1184.

Chesbrough, H. W., West, J., \& Vanhaverbeke, W. (2006). Open Innovation: Researching a New Paradigm. Oxford: Oxford University Press.

Chiaroni, D., Chiesa, V., \& Frattini, F. (2011). The Open Innovation Journey: How firms dynamically implement the emerging innovation management paradigm. Technovation, 31(1), 34-43. doi:10.1016/j.technovation.2009.08.007

Ciborra, C. (1991). Alliances as learning experiments: cooperation, competition and change in high-tech industries. In L.K. Miytelka (Ed). Strategic Partnerships and the World Economy (pp. 51-77). London: Pinter.

Davenport, S., Davies, J., \& Grimes, C. (1999). Collaborative research programmes: building trust from difference. Technovation, 19(1), 31-40.

de Jong, J. P. J., \& Freel, M. (2010). Absorptive capacity and the reach of collaboration in high technology small firms. Research Policy, 39(1), 47-54. doi:10.1016/j.respol.2009.10.003

De Vellis, R. F. (2003). Scale developmet. Theory and applications. EEUU: Thousand Oaks.

del Carmen Haro-Domínguez, M., Arias-Aranda, D., Javier Lloréns-Montes, F., \& Ruíz Moreno, A. (2007). The impact of absorptive capacity on technological acquisitions engineering consulting companies. Technovation, 27(8), 417-425. doi:10.1016/j.technovation.2007.04.003

Easton, G., Easton, A., \& Belch, M. (2003). An experimental investigation of electronic focus groups. Information \& Management, 4O(8), 717-727. doi:10.1016/S0378-7206(02)00098-8

Escribano, A., Fosfuri, A., \& Tribó, J. A. (2009). Managing external knowledge flows: The moderating role of absorptive capacity. Research Policy, 38(1), 96-105. doi:10.1016/j.respol.2008.10.022

Feller, J., Parhankangas, A., Smeds, R., \& Jaatinen, M. (2013). How Companies Learn to Collaborate: Emergence of Improved Inter-Organizational Processes in R\&D Alliances. Organization Studies, 34(3), 313-343. doi:10.1177/0170840612464758

Flatten, T. C., Engelen, A., Zahra, S. A., \& Brettel, M. (2011). A measure of absorptive capacity: Scale development and validation. European Management Journal, 29(2), 98-116. doi:10.1016/j.emj.2010.11.002 
Flatten, T. C., Greve, G. I., \& Brettel, M. (2011). Absorptive Capacity and Firm Performance in SMEs: The Mediating Influence of Strategic Alliances. European Management Review, 8(3), 137-152. doi:10.1111/j.1740-4762.2011.01015.x

Fleming, L., King, C., \& Juda, A. I. (2007). Small Worlds and Regional Innovation. Organization Science, 18(6), 938-954. doi:10.1287/orsc.1070.0289

Fosfuri, A., \& Tribó, J. A. (2008). Exploring the antecedents of potential absorptive capacity and its impact on innovation performance. Omega, 36(2), 173-187. doi:10.1016/j.omega.2006.06.012

Fritsch, M., \& Lukas, R. (2001). Who cooperates on R\&D? Research Policy, 30(2), 297-312. doi:10.1016/S00487333(99)00115-8

Gartner, W. B., \& Thomas, R. J. (1993). Factors affecting new product forecasting accuracy in new firms. Journal of Product Innovation Management, 10(1), 35-52. doi:10.1016/0737-6782(93)90052-R

Grant, R. M. (1991). The Resource-Based Theory of Competitive Advantage: Implications for Strategy Formulation. California Management Review, 33(3), 114-135. doi:10.1016/S0149-2063(99)00037-9

Grant, R. M. (1996). Toward a knowledge-based theory of the firm. Strategic Management Journal, 17(Winter Special Issue), 109-122. doi:10.2307/2486994

Grant, R. M., \& Baden-Fuller, C. (2004). A Knowledge Accessing Theory of Strategic Alliances. Journal of Management Studies, 41(1 January), 61-84.

Gulati, R., Nohria, N. ., \& Zaheer, A. . (2000). Strategic networks. Strategic Management Journal, 21(3), $203-215$. Retrieved from http://www.scopus.com/inward/record.url?eid=2-s2.00000787636\& partnerID=40\&md5=cf2debbf2ee723ce93b6b01b5822874d

Hagedoorn, J. (2002). Inter-firm R\&D partnerships: an overview of major trends and patterns since 1960. Research Policy, 31(4), 477-492. doi:10.1016/S0048-7333(01)00120-2

Hagedoorn, J., Link, A. N., \& Vonortas, N. S. (2000). Research partnerships. Research Policy, 29(4-5), 567-586.

Hagedoorn, J., \& Schakenraad, J. (1993). A Comparison of Private and Subsidized R\&D Partnerships in the European Information Technology Industry. JCMS: Journal of Common Market Studies, 31(3), 373-390. doi:10.1111/j.14685965.1993.tb00470.x

Hassink, R. (1997). Localized industrial learning and innovation policies. European Planning Studies, 5(3), $279-282$. doi:10.1080/09654319708720400

lammarino, S., Piva, M., Vivarelli, M., \& Von Tunzelmann, N. (2012). Technological Capabilities and Patterns of Innovative Cooperation of Firms in the UK Regions. Regional Studies, 46(10), $1283-1301$. doi:10.1080/00343404.2012.679259

Jansen, J. J. P., Van Den Bosch, F. A. J., \& Volberda, H. W. (2005). Managing potential and realized absorptive capacity: How do organizational antecedents matter? Academy of Management Journal, 48(6), 999-1015. doi:10.5465/AMJ.2005.19573106

Kaiser, H. F. (1974). An index of factorial simplicity. Psychometrika, 39(1), 31-36.

Kamberelis, G., \& Dimitriadis, G. (2013). Focus Groups: from structured interviews to collective conversations. Abingdon, Oxon: Routledge, Taylor \& Francis Group.

Kirca, A. H., Jayachandran, S., \& Bearden, W. O. (2005). Market Orientation : A Meta-Analytic Review and Assessment of Its Antecedents and Impact on. Journal of Marketing, 69(April), 24-41.

Kogut, B. (1988). Joint Ventures: Theoretical and Emprirical Perspectives. Strategic Management Journal, 9(4), 319-332.

Kohli, A. K., \& Jaworski, B. J. (1990). Market orientation: the construct, research propositions, and managerial implications. Journal of Marketing, 54, 1-18.

Laursen, K., Leone, M. I., \& Torrisi, S. (2010). Technological exploration through licensing: new insights from the 
licensee's point of view. Industrial and Corporate Change, 19(3), 871-897. doi:10.1093/icc/dtq034

Lefebvre, E., \& Lefebvre, L. A. (1992). Firm innovativeness and CEO characteristics in small manufacturing firms. Journal of Engineering and Technology Management, 9(3-4), 243-277. doi:10.1016/0923-4748(92)90018-Z

Lhuillery, S., \& Pfister, E. (2009). R\&D cooperation and failures in innovation projects: Empirical evidence from French CIS data. Research Policy, 38(1), 45-57. doi:10.1016/j.respol.2008.09.002

Lichtenthaler, U., \& Lichtenthaler, E. (2009). A Capability-Based Framework for Open Innovation: Complementing Absorptive Capacity. Journal of Management Studies, 46(8), 1315-1338. Retrieved from 10.1111/j.14676486.2009.00854.x

López, A. (2008). Determinants of R\&D cooperation: Evidence from Spanish manufacturing firms. International Journal of Industrial Organization, 26(1), 113-136. doi:10.1016/j.jindorg.2006.09.006

Lund Vinding, A. (2006). Absorptive capacity and innovative performance: A human capital approach. Economics of Innovation and New Technology, 15(4-5), 507-517. doi:10.1080/10438590500513057

Lundvall, B. (2007). National Innovation Systems-Analytical Concept and Development Tool. Industry \& Innovation. doi:10.1080/13662710601130863

Lundvall, B. A. (1997). The Globalising Learning Economy: Implications for Innovation Policy. Brussels. Retrieved from http://www.cordis.lu/tser/src/globec.htm

Malerba, F., \& Orsenigo, L. (1997). Technological Regimes and Sectoral Patterns of Innovative Activities. Industrial and Corporate Change, 6(1), 83-118. doi:10.1093/icc/6.1.83

March, J. G. (1991). Exploration and exploitation in organizational learning. Organization Science, 2(1), 71-87.

Martínez-Sánchez, Á. (1992). Regional Innovation and Small High Technology Firms in Peripheral Regions. Small Business Economics, 4, 153-168.

McMillan, S. G. (2015). Exploration and exploitation in science: their impact on sicentific and technological outcomes. International Journal of Innovation Management, 1550017. doi:10.1142/S1363919615500176

Miotti, L., \& Sachwald, F. (2003). Co-operative R\&D: why and with whom? An integrated framework of analysis. Research Policy, 32, 1481-1499.

Mitchell, V. L. (2006). Knowledge integration \& IT Project Performance. MIS Quarterly, 30(4), 919-939.

Mohr, J., \& Spekman, R. (1994). Characteristics of parthership success: partnership attributes, communication behavior, and conflict resolution techniques. Strategic Management Journal, 15, 135-152.

Mora-valentin, E. M., Montoro-sanchez, A., \& Guerras-martin, L. A. (2004). Determining factors in the success of R\&D cooperative agreements between firms and research organizations. Research Policy, 33, 17-40. doi:10.1016/S00487333(03)00087-8

Morgan, D. L. (1988). Focus Groups as Qualitative Research. New- bury Park, Sage Publications, CA,: Sage.

Munns, A., \& Bjeirmi, B. (1996). The role of project management in achieving project success. International Journal of Project Management, 14(2), 81-87. doi:10.1016/0263-7863(95)00057-7

Muscio, A. (2007). The impact of absorptive capacity on SMEs' collaboration. Economics of Innovation and New Technology, 16(8), 653-668.

Narver, J. C., Slater, S. F., \& MacLachlan, D. L. (2004). Responsive and proactive market orientation and new-product success. Journal of Product Innovation Management, 21(5), 334-347. doi:10.1111/j.0737-6782.2004.00086.x

Negassi, S. (2004). R\&D co-operation and innovation a microeconometric study on French firms. Research Policy, 33(3), 365-384. doi:10.1016/j.respol.2003.09.010

Numprasertchai, S., \& Igel, B. (2005). Managing knowledge through collaboration: multiple case studies of managing research in university laboratories in Thailand. Production, 25, 1173-1182. doi:10.1016/j.technovation.2004.03.001 
Nunnally, J. C. (1978). Psychometric Theory, Second ed. NewYork: McGrew-Hill.

Oster, S. M. (1992). Modern competitive analysis. New York: Oxford University Press.

Pavlou, P. a., \& El Sawy, O. A. (2006). From IT Leveraging Competence to Competitive Advantage in Turbulent Environments: The Case of New Product Development. Information Systems Research, 17(3), 198-227. doi:10.1287/isre.1060.0094

Pérez-Luño, A., \& Cambra, J. (2013). Listen to the market: Do its complexity and signals make companies more innovative? Technovation, 33(6-7), 180-192. doi:10.1016/j.technovation.2013.03.001

Project Management Institute. (1987). Guía del PMBOK ${ }^{\circledR}$.

Rundquist, J. (2012). The Ability To Integrate Different Types of Knowledge and Its Effect on Innovation Performance. International Journal of Innovation Management, 16(02), 1250014. doi:10.1142/S1363919612003794

Saebi, T., \& Foss, N. J. (2015). Business models for open innovation: Matching heterogeneous open innovation strategies with business model dimensions. European Management Journal, 33(3), $201-213$. doi:10.1016/j.emj.2014.11.002

Salge, T. O., Bohné, T. M., Farchi, T., \& Piening, E. P. (2012). Harnessing the value of open innovation: The moderating role of innovation management. International Journal of Innovation Management, 16(03), 1240005. doi:10.1142/S1363919612400051

Santamaría, L., Barge-Gil, A., \& Modrego, A. (2010). Public selection and financing of R\&D cooperative projects: Credit versus subsidy funding. Research Policy, 39(4), 549-563. doi:10.1016/j.respol.2010.01.011

Santos-Vijande, M. L., Sanzo-Pérez, M. J., Álvarez-González, L. I., \& Vázquez-Casielles, R. (2005). Organizational learning and market orientation: interface and effects on performance. Industrial Marketing Management, 34(3), $187-202$. doi:10.1016/j.indmarman.2004.08.004

Sanz-Menéndez, L., \& Cruz-Castro, L. (2005). Explaining the Science and Technology Policies of Regional Governments. Regional Studies, 39(7), 939-954. doi:10.1080/00343400500289945

Shimizutani, S., \& Todo, Y. (2008). What determines overseas R\&D activities? The case of Japanese multinational rms. Research Policy, 37, 530-544. doi:10.1016/j.respol.2007.11.010

Slater, S. F., \& Narver, J. C. (1998). Customer-led and market-oriented: Let's not confuse the two. Strategic Management Journal, 19, 1001-1006.

Stock, G. N., Greis, N. P., \& Fischer, W. a. (2001). Absorptive capacity and new product development. The Journal of High Technology Management Research, 12(1), 77-91. doi:10.1016/S1047-8310(00)00040-7

Szulanski, G. (1996). Exploring internal stickiness: Impediments to the transfer of best practice within the firm. Strategic Management Journal, 17(Winter Special Issue), 27-43. doi:10.2307/2486989

Tatikonda, M. V., \& Rosenthal, S. R. (2000). Technology novelty, project complexity, and product development project execution success: a deeper look at task uncertainty in product innovation. IEEE Transactions on Engineering Management, 47(1), 74-87. doi:10.1109/17.820727

Teece, D. J., Pisano, G., \& Shuen, A. (1997). Dynamic capabilities and strategic management. Strategic Management Journal, 18(7), 509-533.

Todorova, G., \& Durisin, B. (2007). Absorptive capacity: valuing a reconceptualization. Academy of Management Review, 32(3), 774-786. doi:10.5465/AMR.2007.25275513

Tomasello, M. V, Napoletano, M., Garas, A., \& Schweitzer, F. (2013). The Rise and Fall of R\&D Networks. arXiv, physics.so(12 Apr 2013), 1-33.

Tsai, W. (2001). Knowledge transfer in intraorganizational networks: effects of network position and absorptive capacity on business unit innovation and performance. Academy of Management Journal, 44(5), 996-1004. doi:10.2307/3069443 
Un, C. A., Cuervo-Cazurra, A., \& Asakawa, K. (2010). R\&D Collaborations and Product Innovation. Journal of Product Innovation Management, 27(5), 673-689. doi:10.1111/j.1540-5885.2010.00744.x

UNE166.001. (2006). UNE 166001:2006. Gestión de la I+D+i: Requisitos de un proyecto de I+D+i.

Varis, M., \& Littunen, H. (2012). SMEs and Their Peripheral Innovation Environment: Reflections from a Finnish Case. European Planning Studies, 20(4), 547-582. doi:10.1080/09654313.2012.665034

Veugelers, R., \& Cassiman, B. (1999). Make and buy in innovation strategies: evidence from Belgian manufacturing firms. Research Policy, 28, 63-80.

Volberda, H. W., Foss, N. J., \& Lyles, M. a. (2010). Absorbing the Concept of Absorptive Capacity: How to Realize Its Potential in the Organization Field. Organization Science, 21(4), 931-951. doi:10.1287/orsc.1090.0503

Weck, M. (2006). Knowledge Creation and Exploitation in Collaborative R \& D Projects : Lessons Learned on Success Factors. Knowledge and Process Management, 13(4), 252-263. doi:10.1002/kpm

West, J., \& Bogers, M. (2014). Leveraging External Sources of Innovation: A Review of Research on Open Innovation. Journal of Product Innovation Management, 31(4), 814-831. doi:10.1111/jpim.12125

West, J., \& Gallagher, S. (2006). Challenges of open innovation: the paradox of firm investment in open-source software. R\&D Management, 36(3), 319-331. doi:10.1111/j.1467-9310.2006.00436.x

Yström, A., Aspenberg, H., \& Kumlin, A. (2015). Exploring the creative climate in an open innovation arena : Identifying challenges and possibilities. European Journal of Innovation Management, 18(1), $70-85$. doi:http://dx.doi.org/10.1108/EJIM-08-2013-0085

Zahra, S. A., \& George, G. (2002). Absorptive Capacity: A Review, Reconceptualization, and Extension. The Academy of Management Review, 27(2), 185. doi:10.2307/4134351

Zollo, M., Reuer, J. J., \& Singh, H. (2002). Interorganizational Routines and Performance in Strategic Alliances. Organiz, 13(6), 701-713.

Zollo, M., \& Winter, S. G. (2002). Deliberate learning and the evolution of dynamic capabilities. Organization Science, 13(3), 339-351. Retrieved from http://www.jstor.org/stable/3086025

\section{Notes}

${ }^{1}$ GDP per capita in 2011 was more than 110\% according to the Regional Accounting of Spanish Institute of Statistics (2010) and own elaboration.

${ }^{2}$ R\&D Statistics (2010). Spanish Institute of Statistics

${ }^{3}$ DICE (2010). Spanish Institute of Statistics and own elaboration.

${ }^{4}$ DICE (2010). Spanish Institute of Statistics

${ }^{5}$ Spanish Patent Office and own elaboration.

${ }^{6}$ According to the Spanish Institute of Statistics in 2010, $42.82 \%$ of the Spanish innovative firms were big (more than 250 employees) and $13.66 \%$ were small, so they found more difficulties to innovate than big companies. Nevertheless in the sample, the $14.49 \%$ were microenterprises and SMEs are represented as well.

${ }^{7}$ All statements from focus group participants included in this paper between quotes have been translated from the Spanish language by the authors themselves

${ }^{8}$ PROFIT was a national program of subsidiaries and credits to firms and Research and Technology Centres (RTOs). A wider analysis about the initiative could be read in the study of Santamaria, et al (2010) (Santamaría, Barge-Gil, \& Modrego, 2010).

9 'Cheque Tecnológico' was a regional imitative for small collaborations between firms and RTOs with subsidiaries with a maximum of 8,000 euros with the support of a regional foundation for science and technology: ARAID, and a credit entity: Ibercaja. 